\title{
17 Characterization of the goat population and breeding practices of goat owners
}

\author{
Surafel Melaku, Alayu Kidane and \\ Aynalem Haile
}

\section{Introduction}

Due to their naturally endowed physiological adaptation and general lower husbandry requirements, goats form an integral part of livestock production in the tropics and subtropics (Morand-Fehr et al., 2004; Mengistu, 2007).

DNA level genetic differences and variations in physical characteristics show that there are four families and twelve breeds of goats in Ethiopia (Farm Africa, 1996; Tucho, 2004). However, genetic characterization of Ethiopian goats by Tucho (2004) was inconsistent with the classification of Farm Africa. Following analysis of fifteen microsatellite loci, the results indicated eight separate genetic entities: the Arsi-Bale, Gumez, Keffa, Woyto-Guji, Abergalle, Afar, Highland goats (previously separated as Central and North West Highland) and goats from the previously known Hararghe, south-eastern Bale and southern Sidamo provinces (Hararghe Highland, Short-eared Somali and Long-eared Somali goats).

According to the Ethiopian sheep and goat productivity improvement programme, there are key identifying physical characteristics that distinguish a breed. A combination of characteristics is required to differentiate one breed from another. The key characteristics that should be observed or measured to identify the breeds of goat population in Ethiopia are coat colour, body size, ear and horn and facial profile (Ayalew and Rowlands, 2004).

The fact that Ethiopia has many different goat breeds, a diverse agro-ecology ranging from cool highlands to hot lowlands and diverse goat production systems, indicates that undertaking characterization studies of the goat populations in various agro-ecologies is very important, as it would provide a benchmark for genetic improvement and biodiversity conservation. This study was also intended to have an input into a sire selection and exchange scheme planned for the Gumara-Maksegnit watershed.

Therefore, this study was conducted with the objective of characterizing the goat population of the Gumara-Maksegnit watershed area based on physical appearance traits and body measurements. 


\section{Materials and methods}

\section{Area description}

The Gumara-Maksegnit watershed lies in the Lake Tana basin of the northwest Amhara region in Ethiopia. This catchment drains into the Gumara river, which ultimately reaches Lake Tana. The Gumara-Maksegnit watershed is found in Gondar Zuria woreda of North Gondar administrative zone. It is located between $37^{\circ} 37^{\prime} \mathrm{E}$ and $12^{\circ} 31^{\prime} \mathrm{N}$ at the upper part of the watershed and $37^{\circ} 33^{\prime} \mathrm{E}$ and $12^{\circ} 24^{\prime} \mathrm{N}$ at the outlet. The watershed is located at about $45 \mathrm{~km}$ south-west of Gondar town. Altitude within the watershed ranges from 1,933 $\mathrm{m}$ to $2,852 \mathrm{~m}$ above sea level. The topography of the area ranges from gentle slope to sharp steep slope. The total area of the Gumara-Maksegnit watershed is about $60 \mathrm{~km}^{2}$. The watershed is inhabited by 1,148 households and 4,246 individuals with an average family size of four persons. Settlement in the watershed is scattered and the landholding is characterized as small and fragmented. About 55 per cent of the total land is cultivable, 23 per cent of the area is covered by forest and grazing land, 7 per cent is waste land and 15 per cent of the land is used for settlement. The livelihood of households in the watershed is dependent on forests, livestock and crop production (Worku, et al., 2010).

\section{Data collection}

Quantitative linear measurement traits including body length, heart girth, wither height, pelvic width and ear length were measured using standard plastic tapes (cm) and body weights were taken using $100 \mathrm{~kg}$ portable balance. A total of 604 goats (435 female, 142 male and 27 castrate) aged about 10 months and above were used for this study.

Physical measurements were taken only from a representative sample of adult animals (as judged by dentition) as recommended by FAO (2012). Scrotal circumference of the male population was also measured. For growth curve construction, dentition and body weight data were collected from a total of 763 goats, including kids at very early ages.

Additionally, data on nine qualitative traits was collected in order to gain a description of the population. These included coat colour type and pattern, presence or absence of ruff and wattle, horn shape and orientation, head profile, ear form and body condition score. Body condition score was assessed subjectively using a 5 point scale $(1=$ very thin, $2=$ thin, $3=$ average, $4=$ fat and $5=$ very fat/obese). The scoring of an animal was done by feeling the backbone and the ribs with the thumb and finger tips.

Moreover, a survey was conducted using a semi-structured questionnaire to study the production system and breeding practices of goat owners. A total of seventy-one households were randomly sampled for the survey from two villages, Dinzaz and Denkele, which were selected with the help of 
development agents based on their suitability for goat production, market and road access.

The questionnaire was designed to obtain information on general household characteristics, the purpose of keeping goats, flock size and structure, ownership and sources of goats, herding and breeding practices and selection criteria for breeding bucks and does. The questionnaire was tested before the survey started to ensure that all questions were clear.

\section{Data analysis}

Prior to analysis the data was checked using the scatter plot method of the Statistical Package for the Social Sciences (SPSS) and the largest and smallest outlier values were filtered out from the data.

The data was analyzed using Statistical Analysis System (SAS) version 9 and SPSS version 16. SPSS was used for descriptive statistical analysis including frequency and percentage analysis, as well as to perform multiple linear regression analysis to determine the prediction equations of body weight using body measurements.

Quantitative measurements were analysed using general linear model (GLM) of SAS. The fixed effects of sex and dentition were considered in the model. A zero pair of permanent incisors (0 PPI) refers to goats with fully grown milk teeth that started to spread apart, wear down or are fully spread apart; 1 PPI means goats with erupted and growing one pair of permanent incisors; 2 PPI includes goats with erupted and growing two pairs of permanent incisors; 3 PPI is goats with erupted and growing three pairs of permanent incisors; 4 PPI encompasses goats with erupted and growing four pairs of permanent incisors and 5 PPI represents goats whose four pairs of permanent incisors have started to wear down, spread apart and are completely lost (broken mouth and smooth mouth). 0 PPI is estimated to be less than 1 year; 1 PPI, 1 to 1.5 years; 2 PPI, 1.5 to 2 years; 3 PPI, 2.5 to 3 years and 4 PPI are grown after more than 3 years of age (ESGPIP, 2009).

Pearson's correlation coefficients between body weight and other linear measurements were computed for the population within each sex and dentition group to see the relationship.

The stepwise regression procedures of SPSS were used to determine the relative importance of live animal body measurements in a model designed to predict body weight. Live weight was regressed on the body measurements separately for each dentition class and for the pooled data by sex categories. The choice of the best fitted regression model was assessed using coefficient of determination $\left(\mathrm{R}^{2}\right)$.

Statistical model employed for linear body measurements

$$
Y_{i j}=\mu+S_{i}+D_{j}+\left(S^{\star} D\right)_{i j}+e_{i j}
$$


where:

$\mathrm{Y}_{\mathrm{ij}}=$ the observations on body weight, wither height, body length, heart girth, pelvic width, ear length and scrotal circumference

$\mu=$ overall mean

$\mathrm{S}_{\mathrm{i}}=$ fixed effect of sex $(\mathrm{k}=$ male, female $)$

$\mathrm{D}_{\mathrm{j}}=$ fixed effect dentition ( $\mathrm{j}=0$ PPI, 1 PPI, 2 PPI, 3 PPI, 4 PPI and $5 \mathrm{PPI})$

$(\mathrm{S} \star \mathrm{D})_{\mathrm{ij}}=$ interaction effect of sex and dentition

$\mathrm{e}_{\mathrm{ij}}=$ error effects.

\section{Multiple linear regression model for females:}

$$
Y_{j}=\beta_{0}+\beta_{1} X_{1}+\beta_{2} X_{2}+\beta_{3} X_{3}+\beta_{4} X_{4}+\beta_{5} X_{5}+e_{j}
$$

where:

$Y_{j}=$ the dependent variable body weight

$\beta_{0}=$ the $\mathrm{y}$ intercept for the independent variables $\mathrm{X}_{1}, \mathrm{X}_{2}, \mathrm{X}_{3}, \mathrm{X}_{4}$ and $\mathrm{X}_{5}$ which are; body length, height at wither, chest girth, pelvic width, ear length, respectively

$\beta_{1}, \beta_{2}, \beta_{3}, \beta_{4}$ and $\beta_{5}$ are the regression coefficients of the variables $X_{1}, X_{2}$, $\mathrm{X}_{3}, \mathrm{X}_{4}$ and $\mathrm{X}_{5}$, respectively

$\mathrm{e}_{\mathrm{j}}=$ the residual error.

\section{Multiple linear regression model for males:}

$$
Y_{j}=\beta_{0}+\beta_{1} X_{1}+\beta_{2} X_{2}+\beta_{3} X_{3}+\beta_{4} X_{4}+\beta_{5} X_{5}+\beta_{6} X_{6}+e_{j}
$$

where:

$Y_{j}=$ the dependent variable body weight

$\beta_{0}=$ the intercept

$\mathrm{X}_{1}, \mathrm{X}_{2}, \mathrm{X}_{3}, \mathrm{X}_{4}, \mathrm{X}_{5}$ and $\mathrm{X}_{6}$ are the independent variables for body length, height at wither, chest girth, pelvic width, ear length and scrotal circumference, respectively $\beta_{1}, \beta_{2}, \beta_{3}, \beta_{4}, \beta_{5}$ and $\beta_{6}$ are the regression coefficients of the variables $X_{1}$, $\mathrm{X}_{2}, \mathrm{X}_{3}, \mathrm{X}_{4}, \mathrm{X}_{5}$ and $\mathrm{X}_{6}$, respectively

$\mathrm{e}_{\mathrm{j}}=$ the residual error.

Indices for both selection criteria and breeding objectives are calculated as:

$$
\text { Index }=\frac{\sum\left(\left(3 \times \mathrm{r}_{1}\right)+\left(2 \times \mathrm{r}_{2}\right)+\left(1 \times \mathrm{r}_{3}\right)\right)}{\sum\left(\left(3 \times \mathrm{R}_{1}\right)+\left(2 \times \mathrm{R}_{2}\right)+\left(1 \times \mathrm{R}_{3}\right)\right)}
$$


where:

$$
\begin{aligned}
\mathrm{r}= & \text { ranks given by farmers for individual selection criteria and } \\
& \text { breeding objectives while } \\
\mathrm{R}= & \begin{array}{l}
\text { ranks given for overall selection criteria and breeding } \\
\text { objectives. }
\end{array}
\end{aligned}
$$

\section{Results and discussion}

\section{Flock composition}

The total number of observations was 764 goats, including kids, obtained from seventy-four participant farmers in the watershed. Therefore, the average goat flock size per household was found to be 8.13. Table 17.1 shows that the number of male goats declined with age, implying that a higher number of females are kept in the flock for longer than male goats. This may be because male goats are taken to market at an early age with only a few breeding bucks kept as sire for their own flock. The small number of castrates at an early age and their increase at dentition 2 indicates the time when farmers practise castration. Flock composition in terms of sex and age has been taken as an indicator of the management system, to some degree the management objectives, flock productivity and constraints on the system (Ibrahim, 1998).

\section{Goat holding}

Flock structure shows that the mean and standard deviation of the goat flock was $3.44 \pm 2.13$ with a range of 1 to 13 for kids, $2.05 \pm 1.52$ with range of

\begin{tabular}{|c|c|c|c|c|c|c|c|c|c|c|}
\hline & & \multicolumn{7}{|c|}{ Dentition } & \multirow[b]{2}{*}{ Total } & \multirow[t]{2}{*}{${ }^{1} A F S H$} \\
\hline & & & 0 & 1 & 2 & 3 & 4 & 5 & & \\
\hline \multirow[t]{6}{*}{ Sex } & Female & $\mathrm{N}$ & 110 & 69 & 42 & 47 & 158 & 9 & 435 & \multirow[t]{6}{*}{8.13} \\
\hline & & $\%$ & 18.2 & 11.4 & 7.0 & 7.8 & 26.2 & 1.5 & 72.0 & \\
\hline & Male & $\mathrm{N}$ & 85 & 12 & 11 & 7 & 27 & NA & 142 & \\
\hline & & $\%$ & 15.0 & 2.1 & 2.0 & 0.8 & 3.6 & - & 23.5 & \\
\hline & Castrate & $\mathrm{N}$ & 1 & 2 & 11 & 3 & 10 & NA & 27 & \\
\hline & & $\%$ & 0.2 & 0.3 & 1.8 & 0.5 & 1.7 & - & 4.5 & \\
\hline \multirow{2}{*}{\multicolumn{2}{|c|}{ Total }} & $\mathrm{N}$ & 196 & 83 & 64 & 57 & 195 & 9 & 604 & \\
\hline & & $\%$ & 33.4 & 13.8 & 10.8 & 8.6 & 31.5 & 1.5 & 100.0 & \\
\hline
\end{tabular}
1 to 7 for kid bucks, $2.52 \pm 1.11$ with range of 1 to 5 for kid does, $1.96 \pm$ 1.62 with range of 1 to 9 for breeding bucks, $4.51 \pm 2.9$ with range of 1 to

Table 17.1 Flock composition by sex and dentition groups

Note: $\mathrm{N}=$ Number of observations; $\mathrm{NA}=$ Not available; ${ }^{1} \mathrm{AFSH}=$ Average flock size per household including kids. 
Table 17.2 Ranking of breeding objectives of goat keeping farmers

\begin{tabular}{lrrrr}
\hline Production objectives & \multicolumn{2}{c}{ Rank } & Index \\
\cline { 2 - 4 } & 1 st & 2nd & 3rd & \\
\hline Cash income & 56 & 13 & 2 & 0.461 \\
Meat & 1 & 21 & 39 & 0.197 \\
Manure & 1 & 6 & 9 & 0.056 \\
Skin & 0 & 0 & 3 & 0.007 \\
Saving & 13 & 31 & 18 & 0.279 \\
\hline
\end{tabular}

Note: Index $=$ sum of $(3 \times$ number of households ranked first $+2 \times$ number of households ranked second $+1 \times$ number of households ranked third) given for each purpose divided by $(3 \times$ total number of households ranked first $+2 \times$ total number of households ranked second $+1 \times$ total number of households ranked third).

20 for breeding does and $1.87 \pm 1.58$ with range of 1 to 7 for castrated males. The total number of goats per household, on average, was found to be 11.31 \pm 7.74 with range of 2 to 52 . Of the total flock, does account for 27.58 per cent, bucks 11.99 per cent, castrates 11.44 per cent, kid bucks 12.54 per cent, kid does 15.41 per cent and kid goats 21.04 per cent. This shows that breeding does formed the major share of the goat population in the watershed followed by kids and kid does.

\section{Purpose of keeping goats}

Ranking of the goat production objectives by smallholder farmers is presented in Table 17.2. The primary reason for keeping goats was found to be generating income followed by saving, meat consumption, manure and skin in order of importance with indices of $0.461,0.279,0.197,0.056$ and 0.007 , respectively.

\section{Selection criteria}

Most of the respondents practise selection of best male and female goats (93 per cent and 98.6 per cent, respectively) as parents of the next generation from their flocks. The selection criteria for breeding does, in order of importance, were: kid growth, height, mothering ability, twinning rate, coat colour and short kidding interval with indices of $0.333,0.217,0.197,0.110$, 0.100 and 0.043 , respectively (Table 17.3 ). Therefore, priority was given to the traits of does that would ensure survival of the kids, and breeders should consider kid growth, doe height, mothering ability and twinning ability as the first four criteria for doe selection. For breeding bucks, height, coat colour, fast growth, libido and horn type and orientation were the selection criteria as prioritized by farmers with indices of $0.404,0.255,0.255,0.071$ and 0.015 , respectively. 
Table 17.3 Ranking farmers' selection criteria for breeding does and bucks

\begin{tabular}{lrrrr}
\hline Selection criteria & \multicolumn{2}{l}{ Rank } & & Index \\
\cline { 2 - 3 } & 1 1st & 2nd & $3 r d$ & \\
\hline Breeding does & & & & \\
$\quad$ Height & 10 & 19 & 23 & 0.217 \\
Coat colour & 5 & 9 & 9 & 0.100 \\
Kid growth & 35 & 11 & 13 & 0.333 \\
Mothering ability & 13 & 16 & 12 & 0.197 \\
Short kidding interval & 2 & 4 & 4 & 0.043 \\
Twinning capacity & 5 & 11 & 9 & 0.110 \\
Breeding bucks & & & & \\
Height & 39 & 18 & 7 & 0.404 \\
Coat colour & 7 & 31 & 18 & 0.255 \\
Horn type and orientation & 0 & 2 & 2 & 0.015 \\
Fast growth & 17 & 10 & 30 & 0.255 \\
Libido & 3 & 5 & 9 & 0.071 \\
\hline
\end{tabular}

Note: Index $=$ sum of $(3 \times$ number of households ranked first $+2 \times$ number of households ranked second $+1 \times$ number of households ranked third) given for each criterion divided by $(3 \times$ total number of households ranked first $+2 \times$ total number of households ranked second $+1 \times$ total number of households ranked third).

\section{Culling and castration}

Most farmers practise culling of does and bucks (94.3 per cent and 91.4 per cent, respectively). The main reasons for culling does were poor mothering ability (24.2 per cent) and poor body condition along with poor mothering ability (22.7 per cent). The main reasons for culling bucks were undesirable colour and poor body condition together (29.7 per cent) followed by poor body condition ( 25 per cent). The primary use of culled goats was to generate income or to slaughter for home consumption (64.2 per cent) and to generate income (35.8 per cent). Most farmers practise culling of does (78.5 per cent) and bucks ( 90.5 per cent) at the age of less than 3 years.

About 77.5 per cent of respondents practised castration of their bucks using traditional (59.3 per cent), modern (37.0 per cent) and both (3.7 per cent) methods. The traditional method of castration is done using wood and round stone to crush the spermatic cord. The average age of castration was $2.29 \pm$ 0.69 years (range $1-3$ years). Most of the farmers ( 45.5 per cent) castrated goats at the age between 2 and 3 years, 41.8 per cent of respondents at the age of above 3 years and 12.7 per cent castrated at the age between 1 and 2 years.

Farmers who castrated their goats during October and June (twice per year) and October to December (within a 3 month period) were 46.3 per cent and 20.4 per cent, respectively. A high proportion (79.6 per cent) of the farmers provided castrate goats with supplements such as oil seed cake, grains, leaves of fodder trees and a local beer by-product (atela) for about 3 months to more than 2 years with irregular patterns and amounts. 
The purpose of castration varied among the farmers. Most of the farmers (70.9 per cent) castrated bucks when they wanted to fatten and sell them, while 14.5 per cent castrated to control breeding as well as to fatten. The third highest reason for castration was fattening along with controlling bucks' behaviour (9.1 per cent) followed by only to control bucks' behaviour (3.6 per cent) and to maintain controlled breeding (1.8 per cent).

\section{Buck holding, mating and kidding patterns}

The average number of intact bucks per household was $1.96 \pm 1.62$ with a range of 1 to 9 , and the average duration of stay for a buck in a flock while serving was $1.18 \pm 0.39$ years with a range of 1 to 2 years. Only 43.7 per cent of respondents had their own buck while 56.3 per cent of respondents used a neighbour's buck ( 87.5 per cent) from communal grazing areas ( 5 per cent) or from neighbours and communal grazing areas ( 7.5 per cent) to mate their does in oestrous in the field. Only 22.6 per cent of respondent farmers practised special care for their buck including additional feeding (85.7 per cent) and health care (14.3 per cent).

From the total respondents who had their own bucks, 74.2 per cent said that their sire serves their own and neighbours' flocks. The second common type of buck service is uncontrolled (19.4 per cent). The sources for replacing breeding bucks were from their own kid bucks (73 per cent), from other farmers' kid bucks (17.5 per cent), from their own kid bucks and the market together (6.3 per cent) and from the market only (3.2 per cent), respectively.

There was no definite mating season; hence kids were born all the year round. However, the months of the year with frequent births were from October to December and June to July (57.9 per cent), from September to November and April to June (32.1 per cent) and November and June (10 per cent), respectively. Farmers cited feed availability (97.1 per cent) as the major reason for the seasonal pattern of kidding.

\section{Reproductive performance}

Reproductive performance of the breeding goat was the single most important factor influencing flock productivity. Estimates of reproductive performance in this study could only be indicative since the information provided by farmers necessarily carried some elements of uncertainty.

\section{Age at sexual maturity and first kidding}

The average (mean \pm SD) age at sexual maturity in male and female goats was $9.74 \pm 2.53$ (range 4-12 months) and $7.61 \pm 2.62$ (range 4-18 months) months, respectively. The average age at first kidding was $13.86 \pm 3.31$ months (range 10-24 months). 
Kidding interval, litter size and reproductive life span of does

The overall mean kidding interval of goats was $6.35 \pm 1.11$ months. This result was lower than the reported kidding interval for Abergelle and Central Highland goats which were $11.31 \pm 2.21$ and $10.3 \pm 1.42$ months, respectively and $8.4 \pm 1.37$ months for Metema goats (Tsegaye, 2009). The overall average litter size was $1.85 \pm 0.36$ kids per doe per kidding. This result was higher than the reported litter size for Abergelle and Central Highland goats which were $1.04 \pm 0.03$ and $1.16 \pm 0.04$ kids per doe per kidding, respectively. The overall mean reproductive lifetime of does in the flock was $9.86 \pm 2.73$ with a range of 6 to 20 years, and the average number of kids per doe per lifetime was 19.99 \pm 7.16 with a range of $8-45$. These results are good indicators of the high reproductive potential of the goats in the area.

\section{Constraints on goat production}

Production constraints, as defined by goat owners in the watershed, are presented in Table 17.4. Disease was the leading goat production constraint (index of 0.31 ) identified in the study area followed by wild animal attack (index of 0.22 ) and feed shortage (index of 0.10). Water shortage, drought, input access, poor performance of the breed, labour shortage, extension service, theft and market access were also cited as constraints on goat production. Low genetic potential of the goat population was not a priority in the study area. This might be due to goat owners' lack of awareness about genotype. However, goat owners' concerns about better height, fast growth and mothering ability were indirect indicators of their interest in improving their goat genotype.

Table 17.4 Ranking production constraints of goat keeping farmers

\begin{tabular}{lrrrrrr}
\hline Production constraints & \multicolumn{2}{l}{ Rank } & \multicolumn{2}{l}{} & Index \\
\cline { 2 - 6 } & 1 st & 2nd & 3rd & 4th & 5 th & \\
\hline Disease & 49 & 12 & 5 & 3 & 0 & 0.31 \\
Feed shortage & 2 & 6 & 13 & 12 & 10 & 0.10 \\
Water shortage & 3 & 5 & 10 & 5 & 3 & 0.08 \\
Labour shortage & 0 & 5 & 4 & 6 & 2 & 0.04 \\
Market access & 0 & 1 & 1 & 1 & 0 & 0.01 \\
Predator/wild animal attack & 11 & 30 & 9 & 7 & 4 & 0.22 \\
Poor performance of breed & 1 & 2 & 6 & 6 & 5 & 0.05 \\
Input access & 0 & 5 & 6 & 7 & 4 & 0.06 \\
Extension service & 0 & 0 & 4 & 2 & 10 & 0.03 \\
Drought & 1 & 2 & 9 & 9 & 13 & 0.07 \\
Theft & 2 & 1 & 0 & 4 & 6 & 0.03 \\
\hline
\end{tabular}

Note: Index $=$ sum of $(5 \times$ number of households ranked first $+4 \times$ number of households ranked second $+3 \times$ number of households ranked third $+2 \times$ number of households ranked fourth + $1 \times$ number of households ranked fifth) given for each purpose divided by $(5 \times$ total number of households ranked first $+4 \times$ total number of households ranked second $+3 \times$ total number of households ranked third $+2 \times$ total number of households ranked fourth $+1 \times$ total number of households ranked fifth). 


\section{2}

S. Melaku et al.

\section{Qualitative physical traits}

Coat colour, pattern and type and physical characteristics of the goat population in the Gumara-Maksegnit watershed area are presented in Table 17.5. The results show that the proportions of plain, patchy and spotted patterns were almost similar. As far as colour type is concerned, white (24.2 per cent) was the dominant plain pattern followed by red with white (19.5 per cent). Hair type was predominantly (88.6 per cent) short fur and smooth. Hairy thighs were observed on 3.9 per cent of females and 2.2 per cent of males. The head profile of 89.4 per cent of the goats was found to be straight. Wattle and ruff were present on only 10.6 per cent and 22.3 per cent of the goats, respectively. About 54 per cent of the goats' ears were carried horizontally and 46 per cent semipendulous. The horn shape for 86.4 per cent of the goats was straight with 91.8 per cent having backward orientation. Polled goats were 1.8 per cent female and 1.3 per cent male of the total population.

\section{Linear body measurements}

The least square means of body measurements of the goat population in the Gumara-Maksegnit watershed as displayed in Table 17.6 were: $33.4 \pm 0.5 \mathrm{~kg}$
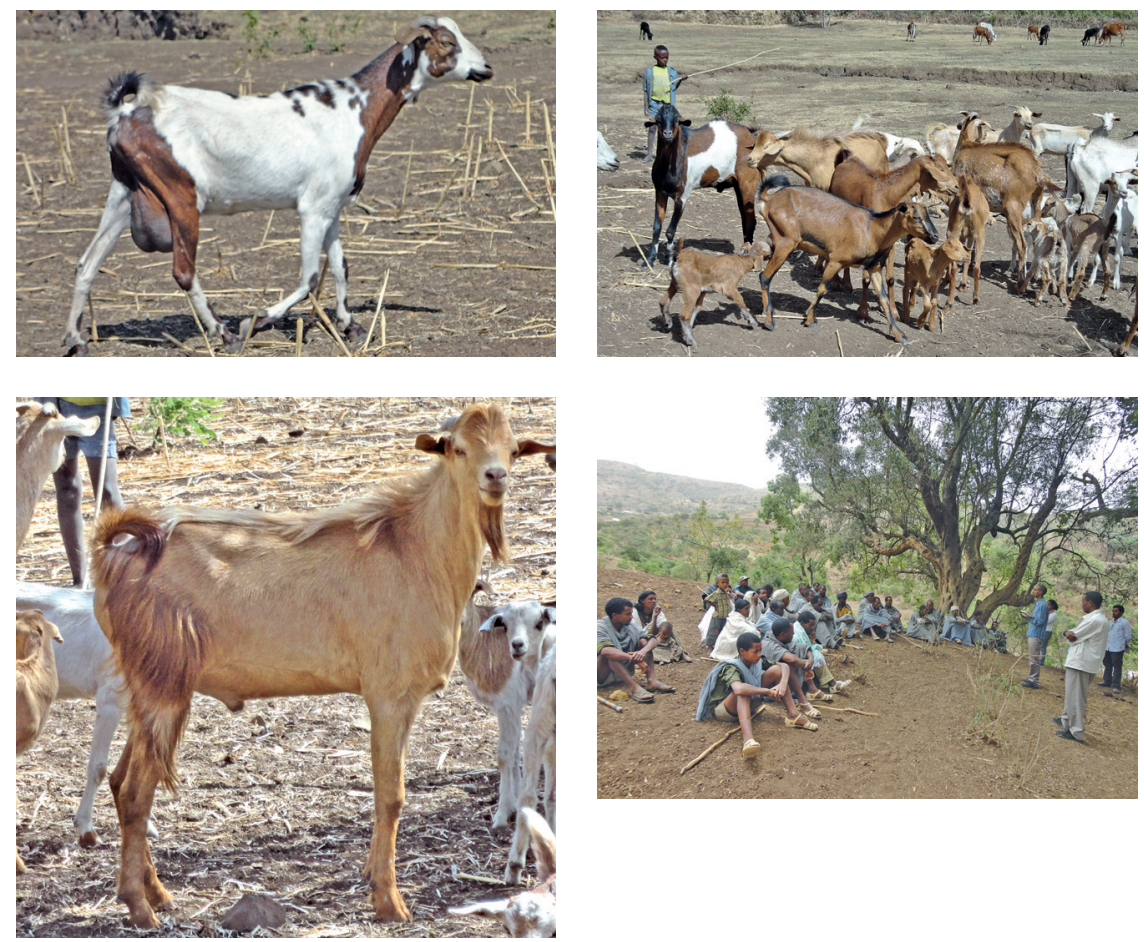

Figure 17.1 Phenotypic appearances of goats in Gumara-Maksegnit watershed and group discussion with farmers in the area 
body weight, $74.4 \pm 0.5 \mathrm{~cm}$ wither height, $62.6 \pm 0.4 \mathrm{~cm}$ body length, 74.2 $\pm 0.5 \mathrm{~cm}$ heart girth, $12.3 \pm 0.1 \mathrm{~cm}$ pelvic width, $13.9 \pm 0.1 \mathrm{~cm}$ ear length, $22.0 \pm 0.4 \mathrm{~cm}$ scrotal circumference and $2.9 \pm 0.1$ body condition score.

Strongly significant differences $(P<0.001)$ were observed in all body measurements and body condition scoring between male and female goats

Table 17.5 Physical body characteristics of goats in Gumara-Maksegnit watershed area

\begin{tabular}{|c|c|c|c|c|c|c|c|}
\hline \multirow[t]{2}{*}{ Traits } & \multirow[t]{2}{*}{ Attribute } & \multicolumn{2}{|c|}{ Female } & \multicolumn{2}{|c|}{ Male } & \multicolumn{2}{|c|}{ Total } \\
\hline & & $N$ & $\%$ & $N$ & $\%$ & $N$ & $\%$ \\
\hline \multirow{3}{*}{$\begin{array}{l}\text { Coat colour } \\
\text { pattern }\end{array}$} & Plain & 135 & 22.4 & 71 & 11.8 & 206 & 34.2 \\
\hline & Patchy & 134 & 22.2 & 54 & 8.9 & 188 & 31.1 \\
\hline & Spotted & 166 & 27.5 & 43 & 7.1 & 209 & 34.7 \\
\hline \multirow{11}{*}{$\begin{array}{l}\text { Coat colour } \\
\text { type }\end{array}$} & White & 88 & 15.4 & 50 & 8.8 & 138 & 24.2 \\
\hline & Black & 5 & 0.5 & 11 & 1.3 & 16 & 1.8 \\
\hline & Grey & 12 & 2.1 & 3 & 0.6 & 15 & 2.6 \\
\hline & Roan & 27 & 3.4 & 20 & 3.1 & 37 & 6.5 \\
\hline & Red and white & 90 & 15.8 & 21 & 3.7 & 111 & 19.5 \\
\hline & White, red and black & 58 & 10.2 & 14 & 2.4 & 72 & 12.6 \\
\hline & Red and black & 19 & 2.1 & 10 & 1.8 & 22 & 3.9 \\
\hline & Roan, white and red & 18 & 3.2 & 5 & 0.9 & 23 & 4.0 \\
\hline & White and black & 11 & 1.9 & 3 & 0.6 & 14 & 2.5 \\
\hline & Fawn and white & 70 & 12.3 & 35 & 6.2 & 105 & 18.4 \\
\hline & $\begin{array}{l}\text { Roan, black and } \\
\text { white }\end{array}$ & 19 & 2.0 & 14 & 2.0 & 23 & 4.0 \\
\hline \multirow[t]{3}{*}{ Hair type } & Fur short and smooth & 393 & 66.6 & 130 & 22.0 & 523 & 88.6 \\
\hline & Fur long and coarse & 13 & 2.2 & 18 & 3.0 & 31 & 5.3 \\
\hline & Fur with hairy thighs & 23 & 3.9 & 13 & 2.2 & 36 & 6.1 \\
\hline \multirow[t]{3}{*}{ Head profile } & Straight & 398 & 66.2 & 139 & 23.2 & 537 & 89.4 \\
\hline & Slightly concave & 31 & 5.2 & 23 & 3.8 & 54 & 9.0 \\
\hline & Markedly concave & 6 & 1.0 & 4 & 0.6 & 10 & 1.6 \\
\hline \multirow[t]{2}{*}{ Wattle } & Absent & 391 & 65.1 & 146 & 24.3 & 537 & 89.4 \\
\hline & Present & 44 & 7.3 & 20 & 3.3 & 64 & 10.6 \\
\hline \multirow[t]{2}{*}{ Ruff } & Absent & 403 & 67.2 & 63 & 10.5 & 466 & 77.7 \\
\hline & Present & 31 & 5.2 & 103 & 17.2 & 134 & 22.3 \\
\hline \multirow[t]{2}{*}{ Ear form } & Carried horizontally & 230 & 38.3 & 94 & 15.6 & 324 & 53.9 \\
\hline & Semi-pendulous & 205 & 34.1 & 72 & 12.0 & 277 & 46.1 \\
\hline \multirow[t]{4}{*}{ Horn shape } & Polled & 11 & 1.8 & 8 & 1.3 & 19 & 3.2 \\
\hline & Scurs & 18 & 3.0 & 13 & 2.2 & 31 & 5.2 \\
\hline & Straight & 385 & 64.1 & 134 & 22.3 & 519 & 86.4 \\
\hline & Curved & 21 & 3.4 & 11 & 1.8 & 32 & 5.2 \\
\hline \multirow{4}{*}{$\begin{array}{l}\text { Horn orien- } \\
\text { tation }\end{array}$} & Obliquely upward & 5 & 0.8 & 3 & 0.5 & 8 & 1.3 \\
\hline & Backward & 404 & 67.3 & 147 & 24.5 & 551 & 91.8 \\
\hline & Polled & 4 & 0.7 & 3 & 0.5 & 7 & 1.2 \\
\hline & Scurs & 21 & 3.5 & 13 & 2.2 & 34 & 5.7 \\
\hline
\end{tabular}

Note: $\mathrm{N}=$ Number of observations. 
except for ear length. Males have higher body sizes than females. Castrates also have larger $P \leqslant 0.01$ body measurements than intact male goats and female goats except ear length. Additionally, castrates were significantly larger $(P<0.01)$ in body weight than mature intact male goats which in turn were larger than mature females.

Except for ear length, all body measurements including body weight showed highly significant variation at 0 to 3 PPI. There was a sharp decline in difference between values for body weight, wither height, body length, chest girth and pelvic width post dentition in group 3. Under normal conditions this is expected, as animals grow fast when younger but more slowly when they reach maturity (Mekasha, 2007). Hence, the goat populations in the area attained maturity at 3 PPI. Moreover, body length, wither height, heart girth and pelvic width showed significant variability in an increasing trend as the animal' advances in age. This implies that the animals' growth patterns could be explained in terms of body measurements. These results are in line with Gebreyesus et al. (2010) who found similar results in the short-eared Somali goat population around Dire Dawa, Ethiopia. Scrotal circumferences at dentition 0 PPI were identical with dentition 1 PPI and 3 PPI but significantly smaller than those at dentition 2 PPI $(P<0.001)$. This can be a good indicator of the age at which the animals attain their maximum sexual maturity and start to decline after the age of 2 years and above, as differences in physiological stage due to age influence body size and testicular growth in domestic animals (Karagiannidis et al., 2000).

The body condition of females was similar to that of males but better $(P<0.001)$ body condition was observed on castrates than either females or males. There was no significant difference in the body condition of goats at 0 , 1 and 2 PPI which were smaller than the goats at later ages ( 3 and 4 PPI). However, the oldest goats at 5 PPI showed thin body condition. In the youngest age group body condition was the same for male and female goats. Mature castrate and intact goats were also identical but significantly $P \leqslant 0.01$ better than those of mature females. This might be explained by the effect of nourishing kids; that breeding does lose condition as they provide milk for their offspring.

\section{Growth curve of the goat population}

Five dentition categories were used for a growth curve of the goat population in the watershed (0 PPI to $5 \mathrm{PPI}$ ). The curve obtained from growth data of the goat population in the scatter plot of Figure 17.2 is close to sigmoid shape (Yakupoğlu 1999). As illustrated in the figure, the growth of the goats can be better explained by a quadratic curve $\left(\mathrm{R}^{2}=72.6\right.$ per cent $)$ than a linear curve $\left(\mathrm{R}^{2}=67.3\right.$ per cent). It can be clearly observed that the goats kept growing at an increasing rate up to dentition 2 and at a declining rate up to dentition 3 . After that, no increase in body weight was noticed on the curve. Therefore, it is possible to conclude that the goats attained maturity at the age of dentition 3 . 


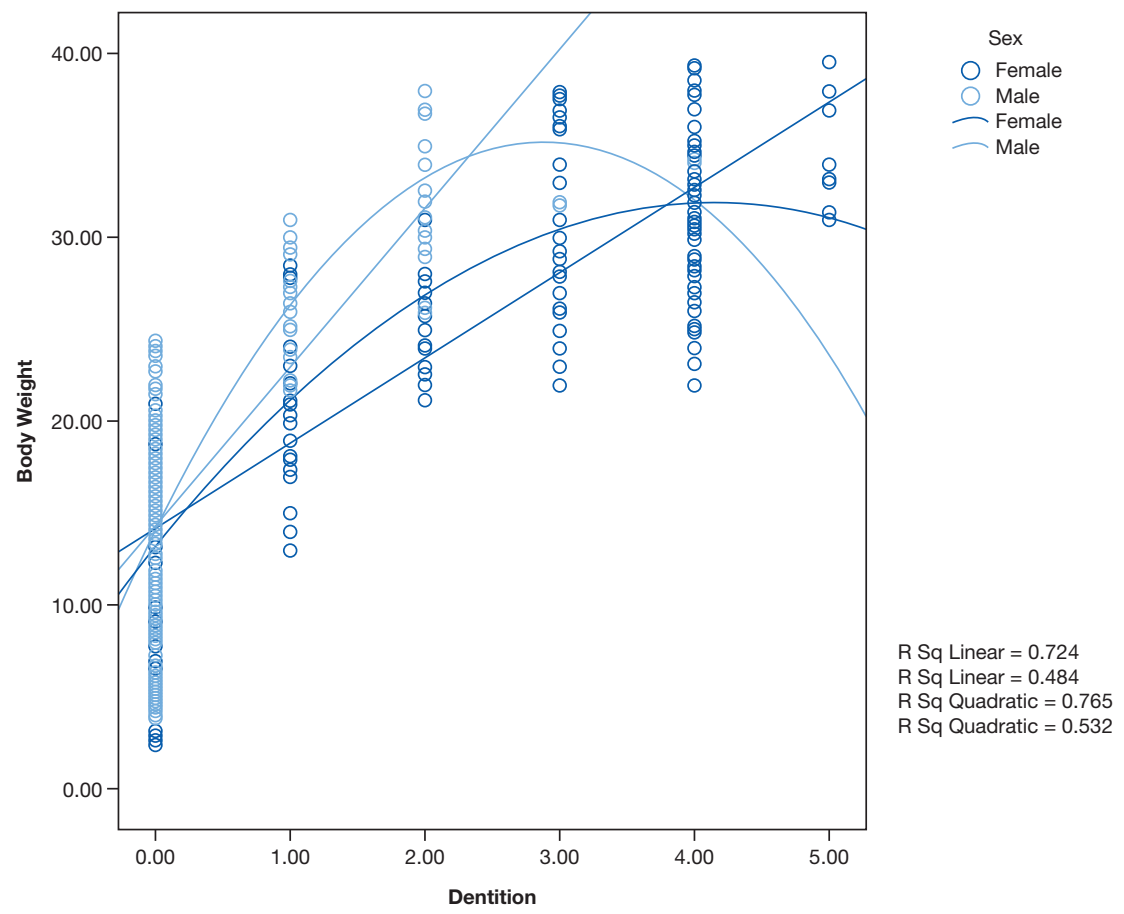

Figure 17.2 Growth curve of goat population in the Gumara-Maksegnit watershed area

\section{Correlation between body weight and body measurements}

Correlation between body weight and other linear body measurement of male and female goats in different age categories were explained by correlation coefficients (r) (Table 17.6). The most significantly correlated body measurement with body weight was heart girth in both male and female goats at all stages of growth. Other body measurements which had strongly positive and highly significant correlations with body weight were wither height, body length and pelvic width in most age categories. The highest association between body weight and heart girth was in the pooled data for males (0.97). This high association between heart girth and body weight indicates that this variable could provide a good estimate in predicting live weight of the population. Studies by Badi et al. (2002) on Barka and Afer goat types, Gebreyesus et al. (2010) on Somali goat types and Slippers et al. (2000) on Nguni goats also found similar results. Scrotal circumference showed the highest association with body weight at the age of 3 to 4 PPI in bucks (0.92) but non-significant correlation at 1 and 2 PPI implying that at maturity (3 PPI and above), goats with larger scrotal circumference may have larger body size. A strong correlation $P \leqslant 0.01$ between body weight and body condition score was only observed for male dentition 2 PPI and pool data. Otherwise, non-significant and negative associations 


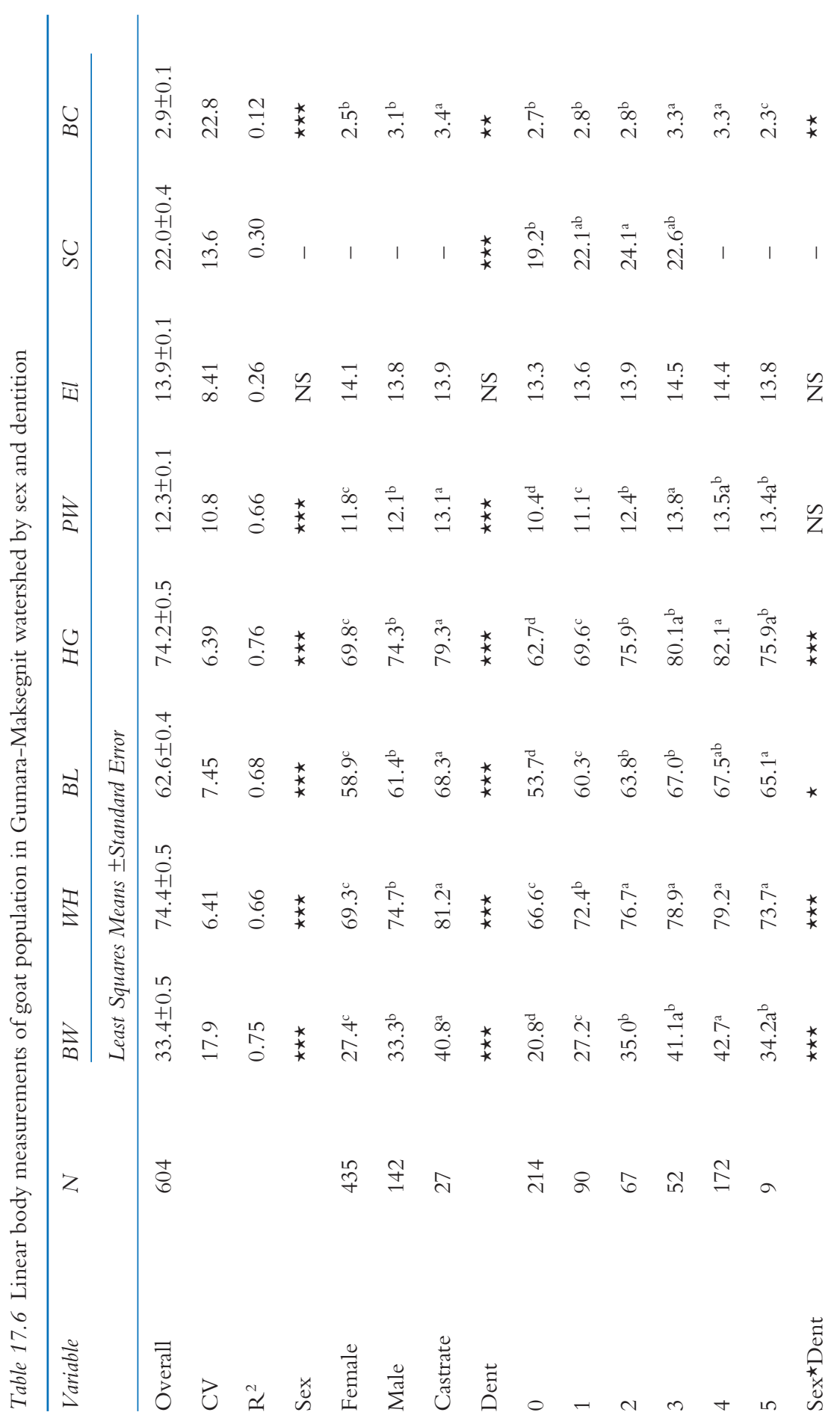




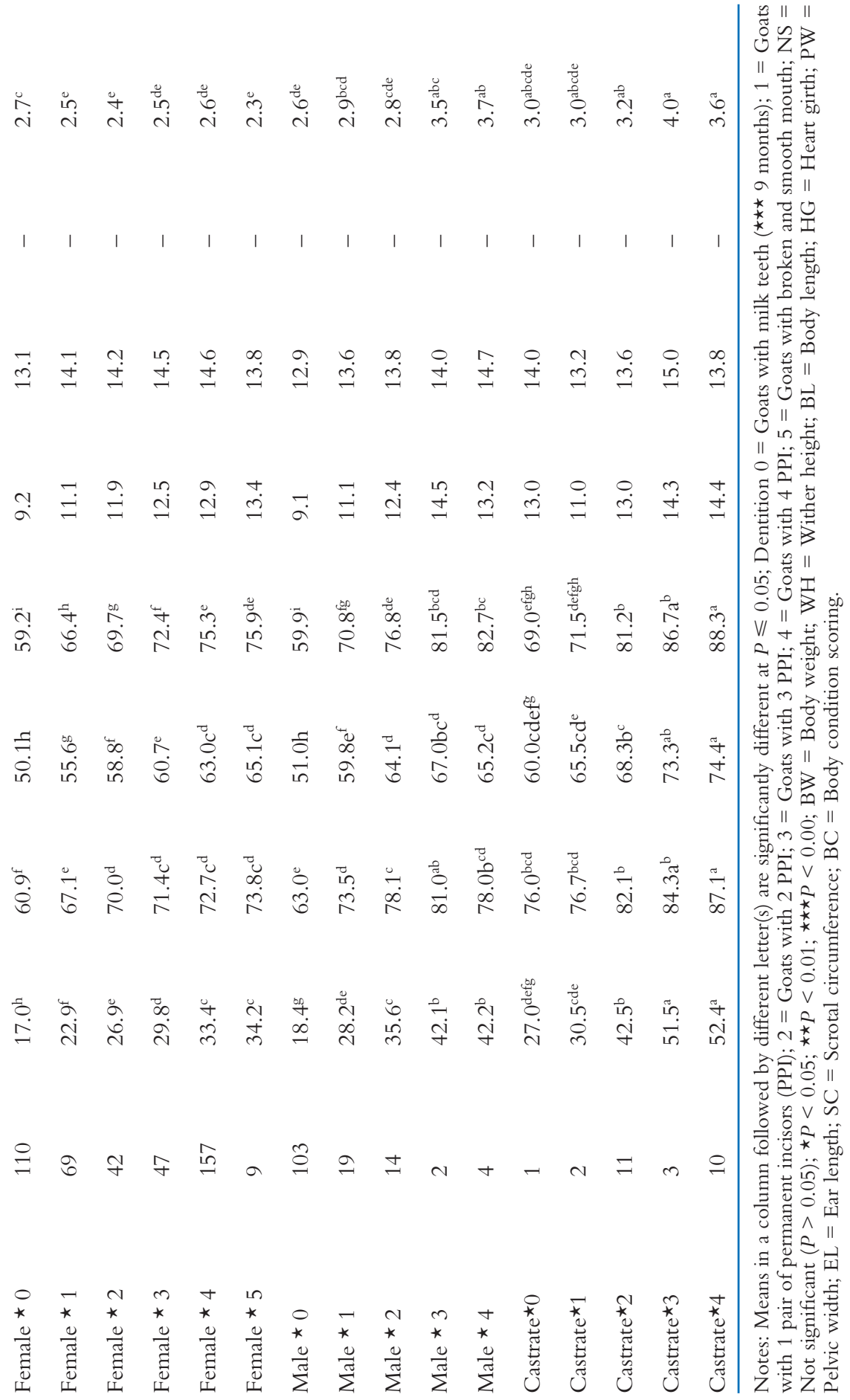




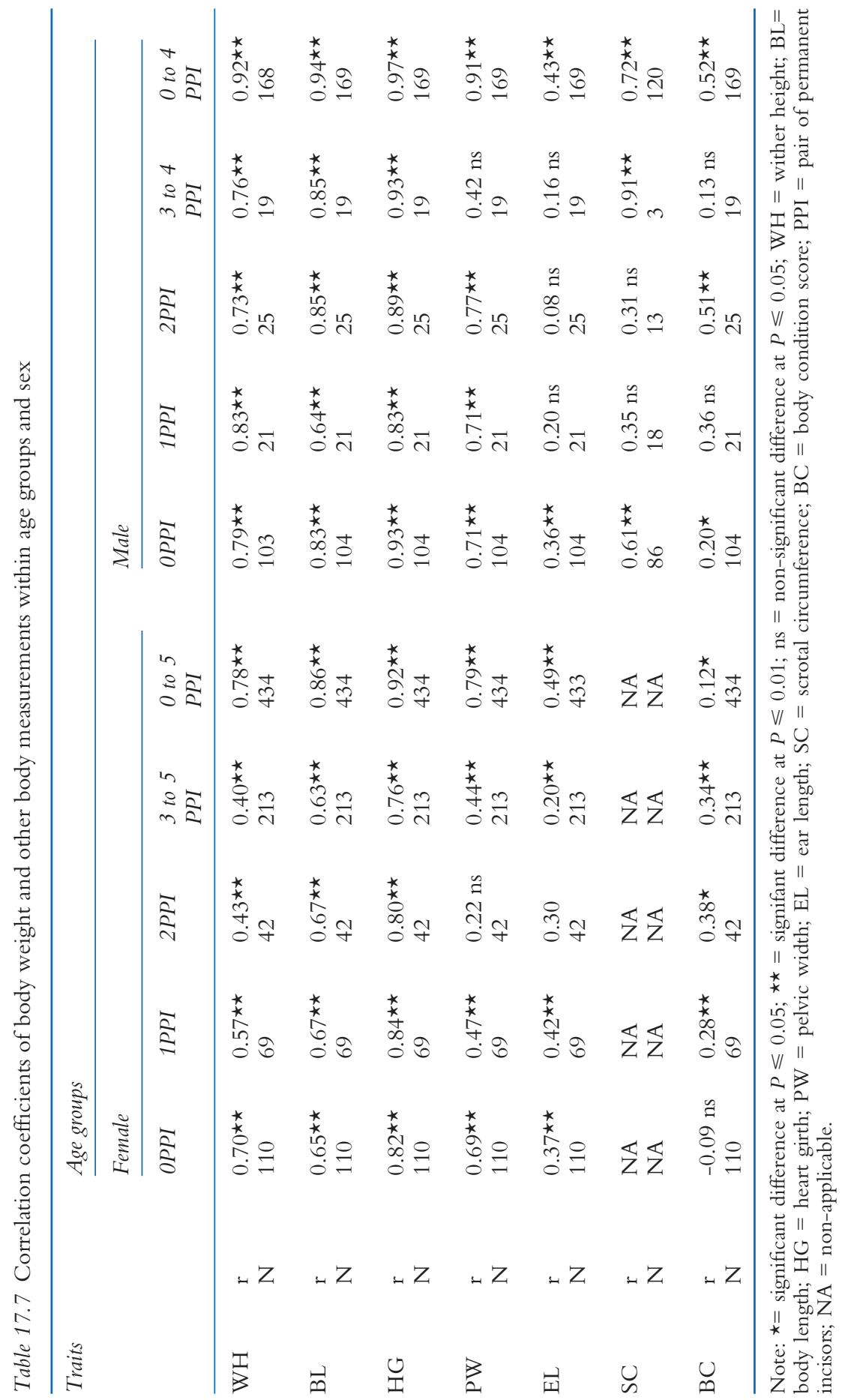


between body weight and body condition scores were observed. This result can be explained by the fact that body condition score is not an important variable in estimating body weight; rather, it shows body reserves in the form of lipid. This was reported in previous studies by Mekasha (2007) and Nsoso et al. (2003).

\section{Prediction of body weight from linear measurements}

Through stepwise elimination procedure, out of six body measurements, those that best fitted the models in the pooled data were heart girth, body length, wither height and pelvic width. However, in the females pooled regression model, only three regressors (heart girth, body length and wither height) and in male goats, three regressors (heart girth, body length and pelvic width), were found to have significant association with body weight at $P<$ 0.05. Heart girth and body length were the variables found to fit best in predicting the live weight of goats when all age categories and both sexes of the goat population were pooled (Table 17.7).

The adjusted coefficient of determination (adjusted $\mathrm{R}^{2}$ ) represents the proportion of the total variability explained by the model. The adjusted $\mathrm{R}^{2}$ values computed for the body measurements were generally higher for the males' pooled data (95.0 per cent) than the pooled data for females (86.0 per cent). This may imply that body weight could be predicted with greater accuracy for males than for their female counterparts. A similar inference was made by Gebreyesus et al. (2010) for higher $\mathrm{R}^{2}$ values of males than females in Short-eared Somali goats.

Heart girth was found to be the best estimator of live weight for both female (adjusted $\mathrm{R}^{2}=84.0$ per cent) and male (adjusted $\mathrm{R}^{2}=95.0$ per cent) goats, and was consistently selected and entered into the model at step one of stepwise regression due to its larger contribution to the model than other variables. Nevertheless, parameter estimates in multiple linear regression models showed that subsequent inclusions of parameters on the heart girth improved the adjusted $\mathrm{R}^{2}$ value from 84 per cent to 86 per cent for does. This suggests that for female goats, body weight could be more accurately predicted by a combination of heart girth and body length than by heart girth alone. Gul et al. (2005) also came up with similar results for Damascus goats. However, measurement of additional traits has cost implications and it may be unpractical to consider many traits under farmers' conditions (though no economic feasibility study was conducted).

Thus, we suggest the following prediction equation for does of pooled age group: $\mathrm{BW}=0.92 \mathrm{HG}-42.8$ and $\mathrm{BW}=0.67 \mathrm{HG}+0.29 \mathrm{BL}-44.3$. For bucks of pooled age group we propose: $\mathrm{BW}=0.97 \mathrm{HG}-45.5$ under farmers' management conditions. 
Table 17.8 Regression models for predicting body weight of goats in GumaraMaksegnit watershed at different age groups

\begin{tabular}{lllllllll}
\hline Dentition $^{1}$ Model $^{2}$ & $b_{0}$ & $b_{1}$ & $b_{2}$ & $b_{3}$ & $\begin{array}{l}\text { Adjust- } \\
R^{2} \\
\text { ed } R^{2}\end{array}$ & $\begin{array}{l}\text { Std } \\
\text { change } \\
\text { error }\end{array}$ \\
\hline Female & & & & & & & & \\
0 & $A \pm b_{1} \mathrm{HG}$ & -22.0 & 0.817 & & & 0.66 & 0.00 & 2.26 \\
& $a \pm b_{1} \mathrm{HG} \pm b_{2} \mathrm{BL}$ & -25.7 & 0.676 & 0.226 & & 0.69 & 0.03 & 2.16 \\
1 & $a \pm b_{1} \mathrm{HG}$ & -44.0 & 0.838 & & & 0.70 & 0.00 & 2.63 \\
& $a \pm b_{1} \mathrm{HG} \pm b_{2} \mathrm{BL}$ & -46.2 & 0.683 & 0.254 & & 0.73 & 0.03 & 2.47 \\
2 & $a \pm b_{1} \mathrm{HG}$ & -30.2 & 0.804 & & & 0.64 & 0.00 & 2.05 \\
& $a \pm b_{1} \mathrm{HG} \pm b_{2} \mathrm{BL}$ & -40.7 & 0.635 & 0.402 & & 0.77 & 0.13 & 1.64 \\
3 & $a \pm b_{1} \mathrm{HG}$ & -55.2 & 0.834 & & & 0.69 & 0.00 & 2.41 \\
& $a \pm b_{1} \mathrm{HG} \pm b_{2} \mathrm{BL}$ & -61.6 & 0.700 & 0.282 & & 0.74 & 0.05 & 2.18 \\
4 & $a \pm b_{1} \mathrm{HG}$ & -48.4 & 0.732 & & & 0.53 & 0.00 & 4.28 \\
& $a \pm b_{1} \mathrm{HG} \pm b_{2} \mathrm{BL}$ & -60.2 & 0.563 & 0.320 & & 0.60 & 0.07 & 3.94 \\
5 & $a \pm b_{1} \mathrm{HG}$ & -52.6 & 0.864 & & & 0.71 & 0.00 & 1.72 \\
Female & $a \pm b_{1} \mathrm{HG}$ & -42.8 & 0.917 & & & 0.84 & 0.00 & 3.33 \\
pooled & $a \pm b_{1} \mathrm{HG} \pm b_{2} \mathrm{BL}$ & -44.3 & 0.672 & 0.288 & & 0.86 & 0.02 & 3.08 \\
& $a \pm b_{1} \mathrm{HG} \pm b_{2} \mathrm{BL} \pm \mathrm{WH}$ & -42.5 & 0.702 & 0.328 & -0.077 & 0.86 & 0.00 & 3.07
\end{tabular}

Male

\begin{tabular}{lllllllll}
0 & $a \pm b_{1} \mathrm{HG}$ & -25.2 & 0.933 & & & 0.87 & 0.00 & 1.56 \\
& $a \pm b_{1} \mathrm{HG} \pm b_{2} \mathrm{BL}$ & -26.3 & 0.740 & 0.239 & & 0.89 & 0.02 & 1.44 \\
1 & $a \pm b_{1} \mathrm{HG}$ & -36.9 & 0.830 & & & 0.67 & 0.00 & 2.22 \\
& $a \pm b_{1} \mathrm{HG} \pm b_{2} \mathrm{BL}$ & -46.5 & 0.679 & 0.332 & & 0.75 & 0.08 & 1.93 \\
& $a \pm b_{1} \mathrm{HG} \pm b_{2} \mathrm{BL} \pm \mathrm{PW}$ & -41.1 & 0.524 & 0.285 & 0.309 & 0.81 & 0.06 & 1.69 \\
2 & $a \pm b_{1} \mathrm{HG}$ & -65.2 & 0.895 & & & 0.79 & 0.00 & 2.86 \\
& $a \pm b_{1} \mathrm{HG} \pm b_{2} \mathrm{BL}$ & -67.8 & 0.583 & 0.410 & & 0.86 & 0.07 & 2.35 \\
& $a \pm b_{1} \mathrm{HG} \pm b_{2} \mathrm{BL} \pm \mathrm{PW}$ & -69.2 & 0.513 & 0.302 & 0.237 & 0.88 & 0.02 & 2.12 \\
3 & $a \pm b_{1} \mathrm{HG}$ & -93.4 & 0.996 & & & 0.99 & 0.00 & 0.99 \\
4 & $a \pm b_{1} \mathrm{HG}$ & -73.4 & 0.900 & & & 0.79 & 0.00 & 3.19 \\
Male & $a \pm b_{1} \mathrm{HG}$ & -45.5 & 0.973 & & & 0.95 & 0.00 & 2.80 \\
pooled & $a \pm b_{1} \mathrm{HG} \pm b_{2} \mathrm{BL}$ & -46.8 & 0.759 & 0.227 & & 0.95 & 0.00 & 2.65 \\
& $a \pm b_{1} \mathrm{HG} \pm b_{2} \mathrm{BL} \pm \mathrm{PW}$ & -45.8 & 0.681 & 0.218 & 0.094 & 0.95 & 0.00 & 2.65 \\
& & & & & & & & \\
Overall & & & & & & & & \\
& $a \pm b_{1} \mathrm{HG}$ & -43.2 & 0.939 & & & 0.88 & 0.00 & 3.28 \\
& $a \pm b_{1} \mathrm{HG} \pm b_{2} \mathrm{BL}$ & -45.3 & 0.692 & 0.278 & & 0.90 & 0.02 & 3.05 \\
\hline
\end{tabular}

Notes: ${ }^{1}$ Dentition $0=$ goats with milk teeth; $1=$ goats with one pair of permanent incisors (PPI); $2=$ two PPI; $3=$ three PPI; $4=$ four PPI and $5=$ goats with broken and smooth mouth ${ }^{2}$ Dependent variables: $\mathrm{BW}=$ Body weight; $\mathrm{HG}=$ Heart girth; $\mathrm{BL}=$ Body length; $\mathrm{WH}=$ Height at wither; PW $=$ Pelvic width. 


\section{Conclusions and recommendations}

Phenotypically, the goat population in the Gumara-Maksegnit watershed area can be characterized by white coat colour in a plain pattern followed by red with white colour in patchy and spotted patterns. Determination of the economic value of these qualitative traits may help in selecting breed improvement alternatives.

As there was no significant change in body weight after eruption of 3 PPI, this age can be considered as the age at which the goat population in the area attains maturity.

Highly significant variation in live weight and body measurement traits of the goats at different stages of growth was noted. This variation suggests the possibility of selection as a promising intervention option for future improvement.

Under farmers' management conditions, heart girth of male goats and a combination of heart girth with body length of female goats, can be used to estimate body weight based on the prediction equations in conditions where measuring live weight is impractical, such as determining dosages of drugs on a live weight basis for a large number of flocks. It is also possible to prepare a reference chart where a list of measurements and proportional body weights can be easily obtained.

The major goat production problems identified were disease, predator and feed shortage in that order of priority. Thus, the development of health care interventions and practising cut and carry feeding strategies using available feeds and the development of adaptive forage species and conservation methods could be helpful.

\section{Acknowledgement}

We would like to thank the International Center for Agricultural Research in the Dry Areas (ICARDA) for financing this research. We sincerely acknowledge researchers at Gondar Agricultural Research Center (GARC) for their support during the collection of data, as well as farmers and development agents in the study areas for their collaboration and participation.

\section{Bibliography}

Ayalew, W. and Rowlands J. (eds), 2004. Design, execution and analysis of the livestock breed survey in Oromiya Regional State, Ethiopia. Oromiya Agricultural Development Bureau, Addis Ababa, Ethiopia and International Livestock Research Institute, Nairobi, Kenya.

Badi, A.M.I., Fissehaye, N. and Rattan, P.J.S., 2002. 'Estimation of live body weight in Eritrean goat from heart girth and height at withers'. Indian Journal of Animal Sciences, 72: 893-5.

Carl, J. and Kees, V.B., 2004. Goat keeping in the tropics (4th edn). Digigrafi, Wageningen, Netherlands. 
Ethiopian Sheep and Goat Productivity Improvement Program, 2009. 'Estimation of weight and age of sheep and goats'. Technical bulletin no.23. Available online at www. esgpip.org/PDF/Technical\%20bulletin\%20No.23.pdf (accessed 11 March 2015).

FAO, 1999. 'The Global Strategy for the Management of Animal Genetic Resources: Executive Brief. Initiative for Domestic Animal Diversity, Food and Agriculture Organization of the United Nations, Rome, Italy.

FAO, 2012. 'Phenotypic characterization of animal genetic resources'. Animal Production and Health Guidelines No. 11, Food and Agriculture Organization of the United Nations Rome, Italy.

Farm Africa, 1996. Goat types of Ethiopia and Eritrea. Physical description and management systems. Farm Africa, London, and International Livestock Research Institute, Nairobi, Kenya.

Gebreyesus, G., Haile, A. and Dese, T., 2010. 'Community-based participatory characterization of the short-eared Somali Goat population around Dire Dawa, Ethiopia'. MSc thesis, Haramaya University, Dire Dawa, Ethiopia.

Gul, S., Gorgulu, O., Keskin, M., Bicer, O. and Sari, A., 2005. 'Some prediction equations of live weight from different body measurements in Shami (Damascus) Goats'. Journal of Animal and Veterinary Advances, 4(5): 532-4.

Ibrahim H., 1998. 'Small ruminant production technique'. ILRI manual 3, International Livestock Research Institute, Nairobi, Kenya.

Karagiannidis, A., Varsakeli, S. and Karatzas, G., 2000. 'Characteristics and seasonal variations in the semen of Alpine, Saanen and Damascus goat bucks born and raised in Greece'. Theriogenology, 53: 1285-93.

Mekasha,Y., 2007. 'Reproductive traits in Ethiopian male goats, with special reference to breed and nutrition'. PhD thesis. Department of Clinical Sciences, Faculty of Veterinary Medicine and Animal Sciences, Swedish University of Agricultural Science, Uppsala, Sweden.

Mengistu, U., 2007. 'Performance of the Ethiopian Somali goats during different watering regimes'. PhD thesis, Department of Anatomy, Physiology and Biochemistry, Swedish University of Agricultural Sciences, Uppsala, Sweden.

Morand-Fehr, P., Boutonnet, J., Devendra, C., Dubef, J.P., Haenlein, G., Holst, P., Mowlem, L., Capote, J., 2004. 'Strategy for goat farming in the 21st century'. Small Ruminant Research, 51(2): 175-83.

Nsoso, S.J., Aganga, B.P., Moganetsi, B.P. and Tshwenyaane, S.O., 2003. 'Body weight, body condition score, and heart girth in indigenous Tswana goats during the dry and wet seasons in southeast Botswana'. Livestock Research for Rural Development, 15: 1-7.

Slippers, S.C., Letty, B.A. and De Villiers, J.F., 2000. 'Predicting the body weight of Nguni goats'. South African Journal of Animal Science, 30 (Supp. 1): 127-8.

Tsegaye, T, 2009. 'Characterization of goat production systems and on-farm evaluation of the growth performance of grazing goats supplemented with different protein sources in Metema woreda, Amhara region, Ethiopia'. MSc thesis, Haramaya University, Dire Dawa, Ethiopia.

Tucho, T.A., 2004. 'Genetic characterization of indigenous goat populations of Ethiopia using microsatellite DNA markers'. PhD thesis, National Dairy Research Institute, India.

Worku, Y., Alem, T., Yeshanew, A., Abegaz, S., Kinde, H., Getinet, A., 2010. 'Socioeconomic survey of Gumara-Maksegnit watershed'. ICARDA-ARARI-EIAR-BOKUSG-2000 project and Gondar Agricultural Research Center, Ethiopia.

Yakupoğlu, C., 1999. 'Etlik Piliçlerde Büyüme Eğrilerinin Kartsılastırılması'. MSc thesis, Institute of Natural Sciences, Ege University, İzmir, Turkey. 